\title{
ALPHA-AMYLASE ACTIVITY IN WHEAT FLOUR AND BREADMAKING PROPERTIES IN RELATION TO DIFFERENT CLIMATIC CONDITIONS
}

\author{
Slađana M. Rakita ${ }^{1 *}$, Aleksandra M. Torbica ${ }^{1}$, Ljubica P. Dokić ${ }^{2}$, Jelena M. Tomić ${ }^{1}$, Milica M. Pojić ${ }^{\text {, }}$ \\ Miroslav S. Hadnađev ${ }^{1}$, Tamara R. Dapčević Hadnađev ${ }^{1}$ \\ ${ }^{1}$ University of Novi Sad, Institute of Food Technology, Bulevar Cara Lazara 1, 21000 Novi Sad, Serbia \\ ${ }^{2}$ University of Novi Sad, Faculty of Technology, 21000 Novi Sad, Bulevar Cara Lazara 1, Serbia
}

\author{
${ }^{*}$ Corresponding author \\ Phone: +381214853808 \\ Fax: +38121450725 \\ E-mail address: sladjana.rakita@fins.uns.ac.rs
}

\begin{abstract}
The aim of the present paper was to evaluate the influence of different climatic conditions on the activity of alpha-amylase in wheat samples and bread quality parameters. Three wheat varieties grown in three different localities in three years were chosen for this study. Commonly used methods for estimation of alpha-amylase activity in wheat grain were employed. The obtained results indicated that harvest year 2013, which was characterized with the excessive amount of rainfall, exhibited the highest level of alpha-amylase activity and the lowest values of the peak viscosity. The lowest alpha-amylase level and the highest peak viscosity and FN value were observed for samples harvested in 2012 which was characterized with the greatest number of days with an average daily temperature above 30 and $35^{\circ} \mathrm{C}$. In addition, a decrease in Mixolab parameter torque C3 and specific bread loaf volume, as well as increase in the breakdown torque (C3-C4) of samples harvested in 2013 were observed, which could be attributed to rainy weather influencing increase in alpha-amylase activity. It is found that specific bread loaf volume of wheat samples is highest in 2012. Moreover, a negative correlation between alpha-amylase activity and specific bread volume for all the samples grown in three years was determined.
\end{abstract}

Keywords: climatic conditions, alpha-amylase, falling number, peak viscosity, bread quality

\section{INTRODUCTION}

Wheat is one of the most important cereals which are grown under different environment conditions worldwide. It has long been recognized that environmental factors have substantial effect on wheat development and thus wheat quality. Stressful weather conditions can take place at any time of the wheat plant development and cause diverse changes in grain morphology and structure (Altenbach et al., 2012; Beckles and Thitisaksakul, 2014). Heat stress and rainfall are recognized as significant factors affecting grain yield and quality in wheat. During grain-filling unfavorable climatic conditions can led to alterations in protein deposition and starch biosynthesis, and thus starch characteristics (Balla et al., 2011). Exposure to high temperatures may severely influence starch accumulation in cereal endosperm due to susceptibility of starch enzymes (Barnabas et al., 2008; Zhao et al., 2008). It is reported that even short period of elevated temperatures $\left(35-40^{\circ} \mathrm{C}\right)$ during grain growth have influence on quality of the grain (Viswanathan and Khanna-Chopra, 2001). Furthermore, large amount of rainfall during grain-filling can significantly increase the level of alpha-amylase, leading to endo- 
sperm starch degradation and impairment of bread quality (Ischinose et al., 2001). The excessive level of alpha-amylase is mainly associated with sprouting which occurs before harvest. Poor quality of end-use products due to high level of alpha-amylase presents huge economic loss to breeders. There are many factors which can significantly affect breadmaking traits. Climatic variations have been considered to be primary factors which can influence the changes in end-use quality. Wheat grain yield and breadmaking properties depend on genotype and environment, as well as their interaction (Denčić et al., 2011).

There have been several methods proposed for estimation of alpha-amylase activity, such as: Amylograph, Hagberg falling number, Rapid Visco Analyser, etc. Brabender Amylograph is approved and standardized method by AACC, ICC and ISO, which monitors changes in pasting properties of heated wheat-water suspension undergoing liquefaction. Hagberg falling number method is a widely used for commercial estimation of alpha-amylase activity, measuring time needed to stir through hot aqueous flour suspension. These methods are indicators of alpha-amylolitic activity, which is determined through its effect on the pasting characteristics. Therefore, lower maximum viscosity or shorter time needed to stir through liquefied starch paste indicate increased alpha-amylase activity, and vice versa. Low value of falling number is generally attributed to preharvest sprouting (Mares and Mrva, 2008); however, alpha-amylase level could be also elevated in the absence of visible sprouting (Kettlewell, 1999). Besides above mentioned methods, Chopin Mixolab is a method commonly employed for determination of starch gelatinization properties which can be affected by activity of amylolitic enzymes (Collar et al., 2007).

There is increasing interest given to the influence of climatic variations on the wheat grain yield and quality. Therefore, the aim of the present paper was to investigate the relationship between wheat flour alpha-amylolitic activity, which has been affected by variable climatic conditions, and parameters of bread quality to develop practical indicator for the estimation of breadmaking quality.

\section{MATERIAL AND METHODS}

\section{Wheat samples}

Three hard white winter wheat varieties $T$. aestivum (Apač, Pobeda and Zvezdana) grown in three different localities in Pannonian plane in Serbia (Bačka Topola - BT, Sremska Mitrovica - SM and Sombor - SO) over three growing seasons (2011, 2012 and 2013) were chosen for the study. Pobeda and Zvezdana were bred by the Institute of Field and Vegetable Crops, Novi Sad, Serbia, whereas Apache was bred by Limagrain, Chappes, France. The measurements of temperature and amount of rainfall at meteorological stations in the three examined localities were observed from the beginning of May until the time of harvest (10th July). Wheat samples were milled to flour using a laboratory mill MLU 202 (Bühler, Uzwil, Switzerland) according to AACC 26-31.

\section{Alpha-amylase assay}

a-Amylase activity of wheat flours was determined by a-amylase kit (Ceralpha, Megazyme Co., Ltd., Wicklow, Ireland). In this method, one unit of alpha-amylase activity is defined as the amount of enzyme releasing $1 \mathrm{mmol}$ of glucose reducing-sugar equivalents per minute under defined assay conditions. Results were expressed in Ceralpha Units (CU) on a dry basis.

\section{Pasting properties}

The maximum amylograph viscosity (MV) was measured using an Amylograph (Brabender Co., Duisburg, Germany) according to ICC Standard No. 126/1.

\section{Hagberg falling number}

Hagberg falling number was measured according to ICC Standard No. 107/1.

\section{Measurement of dough physical pro- perties by Mixolab}

Rheological behavior of wheat flour dough was determined by Mixolab (Chopin, Tri- 
pette et Renaud, Paris, France) using ICC standard No. 173 and Chopin+ protocol. The mixing speed was kept constant at $80 \mathrm{rpm}$. Obtained parameters which were investigated were torques C3 and C3-C4.

\section{Bread making procedure}

The bread dough was formulated of $300 \mathrm{~g}$ of flour (14 g/100 g moisture basis), $2 \%$ fresh yeast (flour basis) and $2 \%$ salt (flour basis). The amount of water required to reach the consistency of 400 Brabender Units (BU) was determined by farinograph data. The dough was mixed for 5 minutes and fermented for $120 \mathrm{~min}$ at $30{ }^{\circ} \mathrm{C}$ and $75 \%$ relative humidity $(\mathrm{RH})$, with punches after 60 and $90 \mathrm{~min}$. Afterwards, the fermented dough was divided into three pieces $(130 \mathrm{~g})$, hand-moulded and proofed for $70 \mathrm{~min}$ at 30 ${ }^{\circ} \mathrm{C}$ and the relative humidity of $75 \% \mathrm{RH}$ for final fermentation. The bread loaves were backed in a MIWE deck baking oven (MIWE Condo, Germany) for $15 \mathrm{~min}$ at $220{ }^{\circ} \mathrm{C}$. After cooling at room temperature for $1 \mathrm{~h}$, the bread volume was determined by using a millet displacement method, while specific volume $\left(\mathrm{cm}^{3} / \mathrm{g}\right)$ was calculated as a ratio of volume and weight.

\section{Statistical analysis}

The effects of three factors (wheat variety, locality and harvest year) on examined parameters were determined using threeway ANOVA. The comparison among means was performed by the Fisher test, and the significant differences were calculated at $p<0.05$. Pearson correlation coefficients $(r)$ for the relationships between investigated parameters were also calculated. Statistical methods were performed using the Software XLSTAT, version (2012.2.02). All measurements were carried out in duplicate, whereas bread making test was performed in triplicate on separate batches.

\section{RESULTS AND DISCUSSION}

According to the presented results (Figure 1) it could be observed that among all three years, year 2013 was dominantly rainfed during the period of post-anthesis. Year 2013 was characterized with excessive amounts of rain in all three investigated localities. Year 2011 had the lowest amount of rainfall in BT and SM, while in SO the level of precipitation was the same as in year 2012.

The greatest number of days with an average daily temperature above 30 and $35^{\circ} \mathrm{C}$ (Figure 2) was in 2012 in all investigated localities. During post-anthesis in 2012 in BT the number of days with an average daily temperature above $30(35){ }^{\circ} \mathrm{C}$ was 31 (10) days, in SM 38 (11) days, while in SO was 28 (7) days. Therefore, year 2012 was characterized with heat stress during crucial period of wheat grain development. The number of days with an average daily temperature above $35{ }^{\circ} \mathrm{C}$ was the lowest in 2011 in all three localities, and thus heat stress was less pronounced.

According to the presented results (Table 1) it could be observed that all selected samples harvested in year 2013 showed higher values of $\alpha$-amylase activity than the samples harvested in 2011 and 2012. This might be a result of weather conditions, precisely, excessive amount of rainfall during harvest year 2013, which caused an increase in alpha-amylase activity. This statement is in agreement with Lunn et al. (2001) who claimed that the alpha-amylase value could be considerably elevated as a consequence of a rainy harvest season. During year 2013 there were large amounts of rain which could interrupt the harvest. Rainfall could lead to pre-harvest sprouting and thus increase the level of germinative enzymes, such as alpha-amylase (Ichinose et al, 2001). However, visible sprouting for wheat samples harvested in 2013 was not detected (data not shown). Barnard (2001) stated that alpha-amylase level could be increased even though no sprouting kernels are determined by visual inspection, adding that grains may undergo initial germination which proceeds without visual sprouting. He also stated that some wheat varieties could have inherent high level of alpha-amylase activity. Samples harvested in 2012 manifested the lowest level of alpha-amylase activity. 


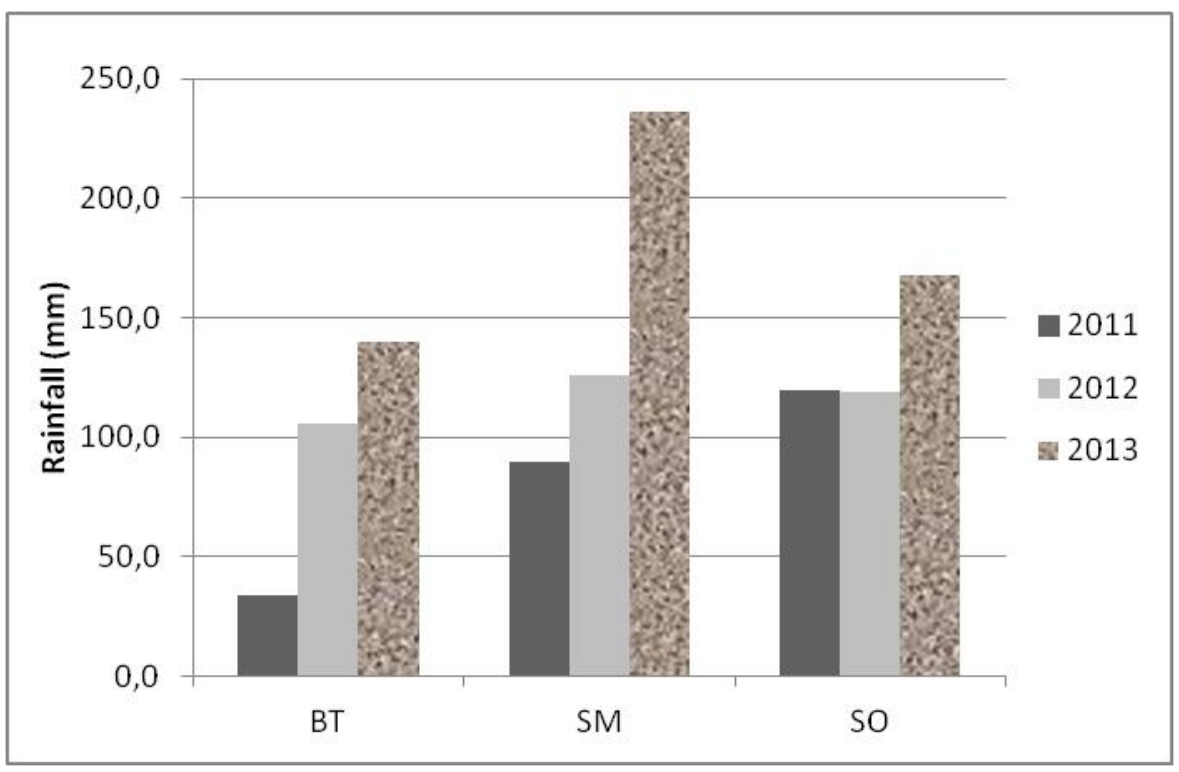

Figure 1. The sum of rainfall in three localities (BT, SM and SO) over 2011, 2012 and 2013 from the beginning of May until $10^{\text {th }}$ July

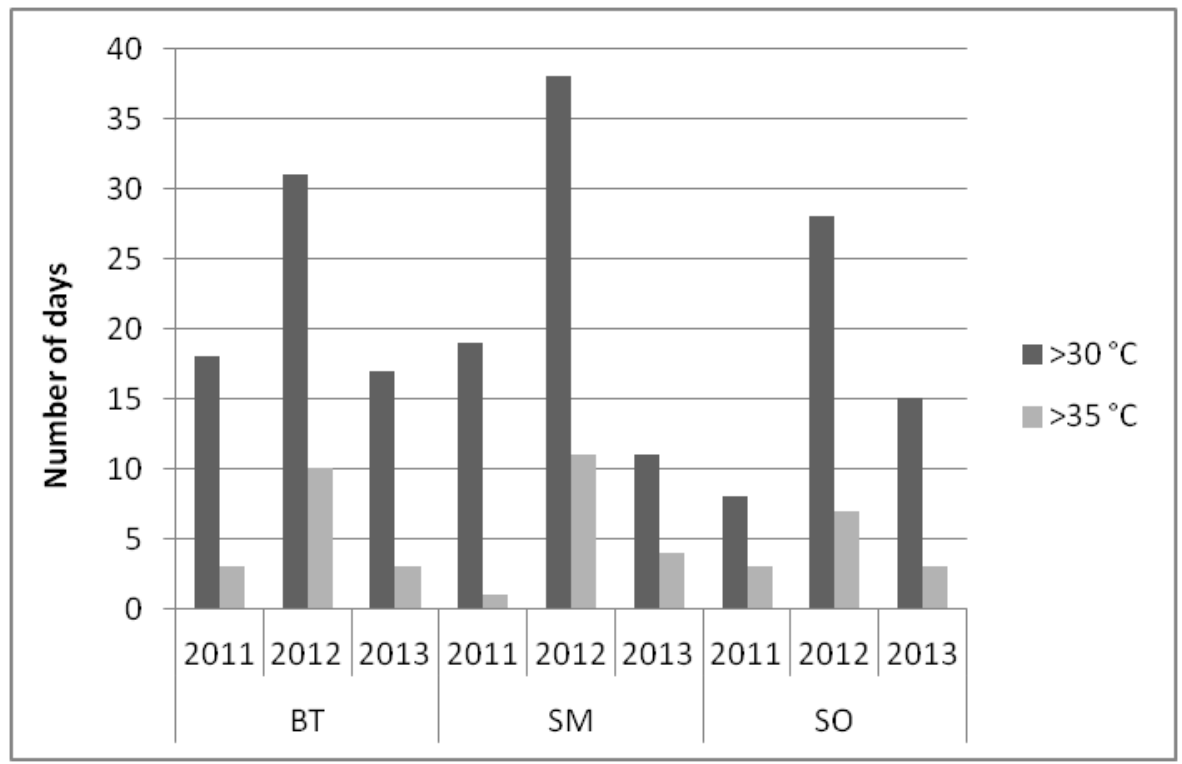

Figure 2. Number of days with an average daily temperature above 30 and $35^{\circ} \mathrm{C}$ in three localities (BT, SM and SO) during three years $\left(2011,2012\right.$ and 2013) from the beginning of May until $10^{\text {th }}$ July

Moreover, wheat flour samples harvested in 2013 exhibited the lowest values of amylograph maximum viscosity (MV), while year 2012 was characterized with the highest MV values. As mentioned above, it could be assumed that the reduction in flour peak viscosity could be result of the increase in alpha-amylase level. It is widely accepted that amylolitic enzymes affect flour pasting properties. Alpha-amylase is endo-acting enzyme which degrades starch molecules thus affecting flour suspension viscosity 
(Noda et al., 2003). Moreover, there is found significant negative correlation $(r=-0.66)$ between these parameters, which confirms the statement of inverse relationship. It could be noticed that, among all varieties, Pobeda expressed the lowest MV values in all localities in three harvest years, which might be attributed to inherent genetic characteristics.
Wheat samples harvested in 2012 demonstrated the highest value of falling number (mean value found to be $460 \mathrm{~s}$ ). Therefore, year 2012 was characterized with the lowest level of alpha-amylase activity and the highest FN values. It is well known that there is inverse relationship between these parameters (Mares et al., 2008).

Table 1. Alpha-amylase activity, Amylograph peak viscosity and falling number values of selected samples

\begin{tabular}{|c|c|c|c|c|c|}
\hline Year & Locality & Variety & CU (\% d.b.) & MV (B.U.) & FN (s) \\
\hline & & Apač & $0.13^{\mathrm{jk}}$ & $1430^{j}$ & $313^{b}$ \\
\hline & BT & Pobeda & $0.09^{\text {efg }}$ & $730^{\mathrm{e}}$ & $385^{d}$ \\
\hline & & Zvezdana & $0.08^{b c}$ & $1700^{n}$ & $411^{\text {gh }}$ \\
\hline & & Apač & $0.14^{\prime}$ & $1500^{k}$ & $421^{\text {hi }}$ \\
\hline \multirow[t]{9}{*}{2011} & SM & Pobeda & $0.13^{\mathrm{kl}}$ & $470^{c}$ & $318^{b}$ \\
\hline & & Zvezdana & $0.09^{\text {def }}$ & $1130^{h}$ & $397^{\text {ef }}$ \\
\hline & & Apač & $0.10^{\text {fgh }}$ & $1585^{\prime}$ & $353^{c}$ \\
\hline & SO & Pobeda & $0.10^{\mathrm{ghi}}$ & $720^{\mathrm{e}}$ & $357^{\mathrm{C}}$ \\
\hline & & Zvezdana & $0.09^{\text {cde }}$ & $1120^{\mathrm{h}}$ & $393^{\mathrm{de}}$ \\
\hline & & Apač & $0,11^{\mathrm{hi}}$ & $1490^{\mathrm{jk}}$ & $449^{\operatorname{Im}}$ \\
\hline & BT & Pobeda & $0.08^{\mathrm{bcd}}$ & $1150^{h}$ & $432^{\mathrm{ijk}}$ \\
\hline & & Zvezdana & $0.07^{\mathrm{ab}}$ & $1610^{\operatorname{lm}}$ & $447^{\mathrm{Im}}$ \\
\hline & & Apač & $0.11^{\mathrm{hi}}$ & $2000^{\circ}$ & $428^{i j}$ \\
\hline \multirow[t]{9}{*}{2012} & SM & Pobeda & $0.08^{\mathrm{bcd}}$ & $960^{f}$ & $457^{\mathrm{m}}$ \\
\hline & & Zvezdana & $0.06^{a}$ & $1580^{\prime}$ & $523^{q}$ \\
\hline & & Apač & $0.11^{\mathrm{hi}}$ & $1670^{\mathrm{mn}}$ & $428^{i j}$ \\
\hline & SO & Pobeda & $0.08^{\text {bcde }}$ & $1350^{i}$ & $457^{m}$ \\
\hline & & Zvezdana & $0.08^{\mathrm{bcd}}$ & $1680^{n}$ & $523^{q}$ \\
\hline & & Apač & $0.17^{\circ}$ & $740^{\mathrm{e}}$ & $433^{\mathrm{jk}}$ \\
\hline & BT & Pobeda & $0.22^{p}$ & $160^{\mathrm{a}}$ & $297^{a}$ \\
\hline & & Zvezdana & $0.12^{\mathrm{ij}}$ & $555^{d}$ & $406^{\mathrm{fg}}$ \\
\hline & & Apač & $0.15^{\mathrm{mn}}$ & $1020 f^{g}$ & $474^{\mathrm{no}}$ \\
\hline \multirow[t]{8}{*}{2013} & SM & Pobeda & $0.15^{n}$ & $360^{b}$ & $441^{\mathrm{kl}}$ \\
\hline & & Zvezdana & $0.11^{\mathrm{hi}}$ & $1020^{\mathrm{fg}}$ & $484^{\circ}$ \\
\hline & & Apač & $0.15^{\mathrm{mn}}$ & $1030^{g}$ & $444^{\prime}$ \\
\hline & so & Pobeda & $0.14^{\mathrm{Im}}$ & $680^{\mathrm{e}}$ & $497^{\mathrm{P}}$ \\
\hline & & Zvezdana & $0.13^{\mathrm{kl}}$ & $1000^{g}$ & $473^{n}$ \\
\hline & & 2011 & 0.11 & 1153 & 372 \\
\hline & Mean & 2012 & 0.09 & 1499 & 460 \\
\hline & & 2013 & 0.15 & 729 & 439 \\
\hline
\end{tabular}

Values followed by the same superscript letter within column are not significantly different $(p<0.05)$ 
Wang et al. (2008) stated that higher FN values could be related to elevated ambient temperature during period of post-anthesis. This is in accordance with the fact that year 2012 had the greatest number of days with an average daily temperature above 30 and $35^{\circ} \mathrm{C}$ during harvest season. However, year 2013 which demonstrated elevated values of alpha-amylase activity did not express the lowest FN mean value. Falling number is a method which measures the alterations in the physical properties of the starch caused by enzymes during the test, rather than actual level of alpha-amylase activity (Johannson, 2002). Endosperm quality and starch properties have also been considered to influence FN values (Dapčević Hadnađev et al., 2011).

Table 2. Selected Mixolab parameters and specific loaf volume of examined samples

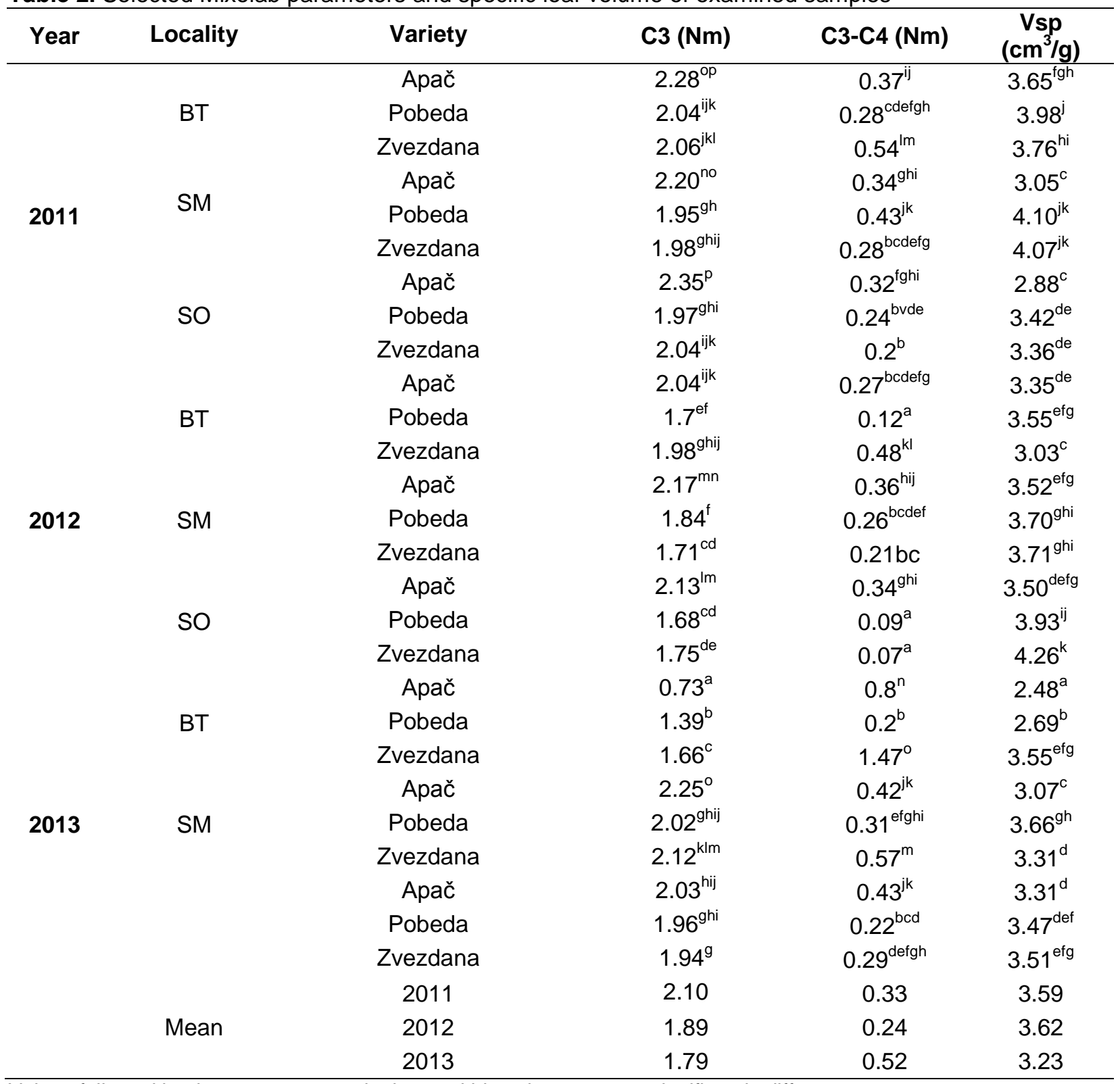

Values followed by the same superscript letter within column are not significantly different $(p<0.05)$ 
Moreover, FN values could be driven by interactions between variety and the weather conditions at the corresponding environment (Wang et al., 2008).

Regarding the obtained Mixolab parameters (Table 2), it could be noticed that the wheat flour samples harvested in year 2013, which also exhibited the highest alpha-amylase levels, had the lowest value of torque C3 (mean value $1.79 \mathrm{Nm}$ ). The torque C3 is affected by the changes in physico-chemical properties of the starch. In the third stage of measurement by a Mixolab device, starch gelatinization occurs. Due to dough heating, denaturated proteins release the water which becomes available for starch granules. With the temperature increase starch granules tend to absorb water, they swell, which leads to the granule disassembling and leaching of the amylose into the medium (Codina et al., 2011). Consequently, dough viscosity elevates thus promoting an increase in the torque C3. The torque C3 could be a measure of alphaamylase activity. There is a negative relationship between these two parameters. The increase in alpha-amylase activity decreases capacity of starch gelatinization, which affects lowering of the torque value (Rosell et al., 2007). Codina et al. (2011) examined the influence of alpha-amylase on Mixolab parameters when added to wheat dough formulation. They revealed the reduction in torques C3 with the increase in enzyme doses. However, in the present study, alpha-amylase level in all samples did not correlate with the torque C3 $(r=-0.28)$.

In the next phase of the measurement, due to the shear stress and the temperature constraint, starch granules degrade, causing the reduction in the dough consistency. Breakdown torque (C3-C4) is also related to amylase activity. The greater the difference between torque C3 and C4 implies the higher level of alpha-amylase activity (Dapčević Hadnađev et al., 2011). Therefore, wheat flour samples harvested in year 2013 exhibited the highest value of the C3-C4 (mean value $0.52 \mathrm{Nm}$ ), whereas year 2012 performed the lowest value (mean value $0.34 \mathrm{Nm}$ ) of the parameter.

Elevated level of alpha-amylase could cause diverse problems in baking quality which can be demonstrated in lower water absorption, mechanical handling deterioration and sticky dough. It has also been observed influence on loaf volume, crumb texture and crumb colour (Sorenson, 2006). Bread loaves of wheat flour samples harvested in year 2013 had lower specific volume (mean value $3.23 \mathrm{~cm}^{3} / \mathrm{g}$ ) when comparing to those harvested in years 2011 and 2012 (mean value $3.59,3.62 \mathrm{~cm}^{3} / \mathrm{g}$, respectively). It could be assumed that rainy weather during post-anthesis in year 2013 affected the increase in alpha-amylase level and thus decrease in specific volume of wheat bread loaves. On contrary, the highest specific loaf volume had wheat samples harvested in 2012, which demonstrated the lowest alphaamylase activity, and the highest peak viscosity and FN values There was found a moderate inverse correlation $(r=-0.55)$ between the alpha-amylase level and Vsp for all selected samples grown over three years. The results were in agreement with the findings of Icninose et al. (2001) who reported the negative correlation $(r=-0.74)$ between these parameters.

\section{CONCLUSIONS}

It was shown that climatic variations during post-anthesis period had influence on wheat flour properties and breadmaking quality. Harvest year 2013, which was characterized with the excessive amount of rainfall, influenced increase in the level of alphaamylase activity which might cause the reduction in peak viscosity, torques $\mathrm{C} 3$ and increase in breakdown torque (C3-C4). Moreover, samples harvested in 2013 exhibited the lowest mean value of specific bread loaf volume. However, increase in alpha-amylase did not influence decrease in falling number value for samples harvested in 2013, as expected. In addition, year 2012 which was characterized with heat-stress had the lowest wheat flour alpha-amylase 
activity and the highest maximum viscosity and falling number value, as well as the highest mean value of specific bread loaf volume. Therefore, level of alpha-amylase activity, which was affected by climatic variations, could be a practical index for the estimation of the value of breadmaking quality.

\section{ACKNOWLEDGEMENTS}

This paper is a result of the research within the project TR 31007 financed by the Ministry of Education, Science and Technological Development, Republic of Serbia.

\section{REFERENCES}

1. AACC (2000). Approved Methods of the AACC (26-31), American Association of Cereals Chemists, St. Paul, MN, USA.

2. Altenbach, S.M. (2012). New insights into the effects of high temperature, drought and post-anthesis fertilizer on wheat grain development. Journal of Cereal Science, 56 (1), 1-12.

3. Balla, K., Rakszegi, M., Békés, F., Bencze, S., Veisz, O. (2011). Quality of winter wheat in relation to heat and drought shock after anthesis. Czech Journal of Food Science, 29 (2), 117-128.

4. Barnabás, B., Jäger, K., Fehér, A. (2008). The effect of drought and heat stress on reproductive processes in cereals. Plant, Cell and Environment, 31, 11-38.

5. Barnard, A. (2001). Genetic diversity of South African winter wheat cultivars in relation to preharvest sprouting and falling number. Euphytica, 119, 107-110.

6. Beckles, D., Thitisaksakul, M. (2014). How environmental stress affects starch composition and functionality in cereal endosperm. Starch/Stärke, 66, 58-71.

7. Codina, G.G., Mironeasa, S., Mironeasa, C.J. (2011). Variability and relationship among mixolab and falling number evaluation based on influence of fungal $\alpha$ - amylase addition. Journal of Agricultural Science and Technology, 92, 2162-2170.

8. Collar, C., Bollain, C., Rosell, C.M. (2007). Rheological behavior of formulated bread doughs during mixing and heating. Food Science and Technology, 13 (2), 99-107.

9. Dapčević Hadnađev, T., Pojić, M., Hadnađev, M., Torbica, A. (2011). The role of em- pirical rheology in flour quality control. In Wide Spectra of Quality Control. Eds. I. Akyar, InTech, Rijeka, pp. 335-360.

10. Dapčević Hadnađev, T., Torbica, A., Hadnađev M. (2011). Rheological properties of wheat flour substitutes/alternative crops assessed by Mixolab. $11^{\text {th }}$ International Congress on Engineering and Food (ICEF11), Athens, Greece, Proceedings, pp. 328-334.

11. Denčić, S., Mladenov, N., Kobiljski, B. (2011). Effects of genotype and environment on breadmaking quality in wheat. International Journal of Plant Production, 5 (1), 7182.

12. ICC STANDARDS. (1996). International Association for Cereal Science and Technology, Standard methods No: 107/1, 126/1 and 173, Vienna.

13. Ichinose, Y., Takata, K., Kubabara, T., Iriki, N., Abiko, T., \& Yamauchi, H. (2001). Effects of increase in alpha-amylase and endoprotease activities during germination on the bread making quality of wheat. Food Science and Technology Research, 7, 214219.

14. Johansson, E. (2002). Effect of two wheat genotypes and Swedish environment on falling number, amylase activities, and protein concentration and composition. Euphytica, 126, 143-149.

15. Kettlewell, P.S. (1999). The response of alpha-amylase activity during wheat grain development to nitrogen fertilizer. Annals of. Applied Biology, 134, 241-249.

16. Lunn, G.D., Major, B.J., Kettlewell, P.S., Scott, R.K. (2001). Mechanisms leading to excess alpha-amylase activity in wheat (Triticum aestivum L.) grain in the U.K. Journal of Cereal Science, 33, 313-329.

17. Mares, D., Mrva, K. (2008). Late-maturity aamylase: Low falling number in wheat in the absence of preharvest sprouting. Journal of Cereal Science, 47, 6-17.

18. Noda, T., Ichinose, Y.,Takigawa, S., Matsuura-Endo C., Abe, H., Saito, K., Hashimoto, N., Yamauchi, H. (2001). The pasting properties of flour and starch in wheat grain damaged by $\alpha$-amylase. Food Science Technology Research, 9 (4), 387-391.

19. Rosell C. M., Collar, C., Haros, M. (2007). Assessment of hydrocolloid effects on the thermo-mechanical properties of wheat using 
the Mixolab. Food Hydrocolloids, 21, 452462.

20. Sorenson, B. (2006). Falling Numbers 101: Determining Sprout Damage in Grain, In: Praire grains.

(http://www.smallgrains.org/springwh/Mar06/ falling/falling.html).

21. Wang, J., Pawelzik, E., Weinert, J., Zhao, Q., Wolf, G.A. (2008). Factors influencing falling number in winter wheat. European Food Research Technology, 226, 13651371.
22. Wisvanthan, C., Khanna-Chopra, R. (2001). Effect of heat stress on grain growth, starch synthesis and protein synthesis in grains of wheat (Triticum aestivum L.) varieties differring in grain weight stability. Journal of Agronomy \& Crop Science, 186, 1-7.

23. Zhao, H., Dai, T., Jiang, D., Cao, W. (2008). Effects of high temperature on key enzymes involved in starch and protein formation in grains of two wheat cultivars. Journal of Agronomy \& Crop Science, 194, 47-54.

\title{
АКТИВНОСТ АЛФА-АМИЛАЗЕ У ПШЕНИЧННОМ БРАШНУ И КАРАКТЕРИСТИКЕ ХЛЕБА У ПОГЛЕДУ РАЗЛИЧИТИХ КЛИМАТСКИХ УсЛОВА
}

\author{
Слађана М. Ракита ${ }^{1 *}$, Александра М. Торбица ${ }^{1}$, Љубица П. Докић ${ }^{2}$, Јелена Томић ${ }^{1}$, Милица М. \\ Појић ${ }^{1}$, Мирослав С. Хаднађев ${ }^{1}$, Тамара Р. Дапчевић Хаднађев ${ }^{1}$ \\ ${ }^{1}$ Универзитет у Новом Саду, Научни институт за прехрамбене технологије у Новом Саду, \\ 21000 Нови Сад, Булевар Цара Лазара 1, Србија \\ ${ }^{2}$ Универзитет у Новом Саду, Технолошки факултет, 21000 Нови Сад, Булевар Цара Лазара. 1 , \\ Србија
}

Сажетак: Циљ овог истраживања био је да се испита утицај различитих климатских услова на активност алфа-амилазе пшенице и квалитет хлеба као готовог производа. У ову сврху испитиване су три различите сорте пшенице које су гајене на три различита локалитета у Србији током три године. Коришћене су методе које се најчешће примењују за процену амилолитичке активности. На основу добијених резултата могло се закључити да су узорци из године 2013, која је карактерисана као година са највећом количином падавина, имали највећи ниво алфа-амилазе и најмању вредност максималног вискозитета мереног помоћу Брабендеровог амилографра. Најмања алфа-амилазна активност и највиша вредност максималног вискозитета и броја падања је примећена у узорцима из 2012. године, која је имала највећи број дана са просечном дневном температуром изнад 30 и $35{ }^{\circ} \mathrm{C}$ у периоду пре жетве, односно била је карактеристична по топлотном стресу. Дошло је до смањења вредности торзије С3 и специфичне запремине хлеба, као и повећање разлике С3-С4 у узорцима из 2013 године, што би се могло приписати повећаној алфаамилазној активности изазваној великим количинама падавина. Најмању запремину хлеба су имали узорци из 2012. године. Такође је утврђено да постоји негативна корелација између активности алфа-амилазе и специфичне запремине хлеба за све испитиване узорке гајене током три године.

Кључне речи: климатски услови, алфа-амилаза, максимални вискозитет, број падања, квалитет хлеба

Received: 19 October 2015 